\title{
As imagens do jornalista Héctor Florencio Varela sobre Madame Lynch e o Paraguai no pós-Guerra da Tríplice Aliança
}

Natania Neres da Silva ${ }^{1}$

\begin{abstract}
Resumo: Este artigo integra uma pesquisa que investiga diferentes biografias sobre Elisa Lynch, companheira do marechal Solano López. Lynch tornou-se uma personagem importante na Guerra da Tríplice Aliança (1864-1870) e sua trajetória de vida foi discutida por diversos biógrafos. O conflito no Cone Sul é um dos episódios mais estudados entre os paraguaios e, por consequência, as figuras políticas mais conhecidas que participaram do embate - como é o caso de Lynch e López - ainda despertam muita atenção e interesse. Analisaremos neste artigo como o argentino Héctor Varela, através da biografia Elisa Lynch por Orion (1870), optou por retratar essa personagem no período imediatamente posterior à luta armada. No final do século XIX, predominou uma leitura que responsabilizava Solano López pela declaração de guerra. Veremos como Varela dialogou com essa interpretação sobre o conflito, fazendo comentários maledicentes tanto sobre Elisa Lynch quanto sobre o governo paraguaio.
\end{abstract}

Palavras-chave: Paraguai, Guerra da Tríplice Aliança, Elisa Lynch.

\section{The images of the journalist Héctor Florencio Varela about Madame Lynch and Paraguay in the post-Triple Alliance War}

\begin{abstract}
This article is part of a research that investigates biographies on Elisa Lynch, the spouse of Solano López. Lynch became an important figure in the War of the Triple Alliance in Paraguay (1864-1870); several biographers discussed her life story. The conflict in the Southern Cone is one of the most studied topics among the Paraguayans and, as a result, the most well-known political figures who participated in the war such as Lynch and López - still attract much attention and interest. This article analyses how Héctor Varela, an Argentinian writer, chose to portray Lynch in the period immediately after the war, in the biography Elisa Lynch por Orion (1870). At the end of the nineteenth century, the interpretation that blamed Solano López for starting the war predominated. The biographer Héctor Varela dialogued with this interpretation about the conflict, making slanderous remarks about both Elisa Lynch and the Paraguayan government.
\end{abstract}

Keywords: Paraguay, Triple Alliance War (Paraguayan War), Eliza Lynch.

\footnotetext{
${ }^{1}$ Mestranda no programa de pós-graduação em História Social da Universidade de São Paulo (USP), São Paulo, Brasil, tendo contado com apoio financeiro parcial da Fundação de Amparo à Pesquisa do Estado de São Paulo (FAPESP), processo no: 2016/01458-9. É Integrante do Laboratório de Estudos de História das Américas (LEHA) da USP, do "Ñande" - Rede de Pesquisadoras e Pesquisadores sobre o Paraguay e do Grupo de Pesquisa em Gênero e História (GRUPEG-HIST). E-mail para contato: natania.n.silva@gmail.com
}

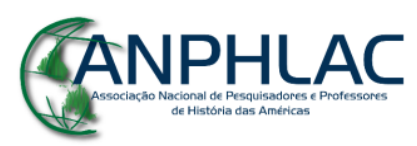

Revista Eletrônica da ANPHLAC, ISSN 1679-1061, №. 24, p. 44-71, Jan./Jun., 2018.

http://revista.anphlac.org.br 
Artigo recebido em: $31 / 12 / 2017$

Artigo aprovado para publicação em: 11/03/2018

\section{Introdução}

O Paraguai, assim como outros países, possui uma exitosa narrativa histórica da nação. Exitosa não por ser um enredo repleto de glórias e vitórias; pelo contrário, o interessante da narrativa paraguaia é que ela logrou produzir uma cosmogonia repleta de heróis e histórias fantásticas, mesmo em um cenário desfavorável, com a perda de uma guerra e a dizimação de grande parte de sua população. A Guerra da Tríplice Aliança (1864-1870) - que os brasileiros geralmente conhecem como Guerra do Paraguai - é o episódio principal dessa trama. ${ }^{2}$ Todos os demais acontecimentos da história do país foram e ainda são interpretados à luz dessa tragédia; a todo o momento, os paraguaios se referem a ela.

Embora a Guerra da Tríplice Aliança tenha terminado oficialmente em 1870, com a morte do presidente e marechal paraguaio Francisco Solano López, o conflito ainda se apresenta como essencial e recorrente no país, transcendendo em muito os limites que a produção acadêmica frequentemente possui, alcançando uma repercussão significativa e pouco comparável com a relevância que a temática possui na historiografia brasileira. Os "heróis" paraguaios são constantemente mobilizados no país: seus nomes batizam importantes avenidas e ruas, e seus rostos estão cunhados em moedas paraguaias. Além disso, museus, monumentos e outras edificações relacionadas ao conflito estão espalhados pela capital. A guerra está presente no cotidiano dos paraguaios, é mobilizada em protestos estudantis, encenada em peças teatrais e comemorada em feriados, como é o caso do día de los Héroes de la Patria. ${ }^{3}$ Afirmar a relevância e atualidade da temática não implica, no entanto, sustentar a ideia de que há um consenso geral em torno dos significados atribuídos à guerra pelos paraguaios; seria possível discutir longamente a respeito desses múltiplos sentidos.

\footnotetext{
${ }^{2}$ A Guerra da Tríplice Aliança envolveu o Brasil, a Argentina e o Uruguai, que formaram uma coalizão militar que derrotou o Paraguai.

${ }^{3}$ O Día de los Héroes de la Patria é um feriado nacional comemorado no dia primeiro de março. Essa data foi escolhida para homenagear o "heroísmo" do marechal Francisco Solano López, que foi morto pelo exército brasileiro nessa mesma data em 1870.
}

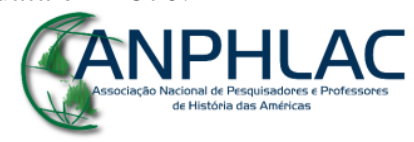

Revista Eletrônica da ANPHLAC, ISSN 1679-1061, №. 24, p. 44-71, Jan./Jun., 2018.

http://revista.anphlac.org.br 
Essa narrativa heroica da nação paraguaia foi elaborada e ressignificada nos últimos cento e cinquenta anos. A historiografia do país, em suas sucessivas transformações, também ofereceu contribuições que ajudaram a difundir ou refutar leituras nacionalistas a respeito da Guerra da Tríplice Aliança, do marechal López e da atuação dos soldados e das residentas ${ }^{4}$ paraguaias. $^{5}$ A ditadura militar paraguaia (19541989), chefiada por Alfredo Stroessner, foi a grande responsável pelo engrandecimento e consolidação dessa narrativa nacionalista e lopista, vinculada à exaltação do marechal López (LAMBERT, 2013, p. 335-358). Apoiando-se no revisionismo historiográfico sobre a guerra, o ditador levou o lopismo ao seu auge, enaltecendo não somente os grandes líderes militares, mas também os "heróis anônimos" que se sacrificaram para salvar a pátria (CAPDEVILA, 2010, p. 231).

Nessa cosmogonia heroica, uma personagem que se evidencia de forma polêmica é uma mulher de origem irlandesa que se chamava Elisa Alicia Lynch (18341886), comumente reconhecida como Madame Lynch, e que veio a se tornar a companheira do presidente paraguaio, vivenciando o conflito intensamente desde a declaração de guerra. Há uma longa produção de caráter biográfico a respeito de Madame Lynch que, grosso modo, ora a inclui no "panteão de heróis" paraguaios - pelo fato dela ter acompanhado o presidente durante toda a guerra -, ora a exclui da narrativa nacionalista - por ela, supostamente, ter sido uma prostituta que López trouxe da Europa, uma mulher que apenas desejava enriquecer e viver luxuosamente às custas do governo paraguaio. Setenta e cinco anos após Madame Lynch morrer no ostracismo e no "exílio", na França, o ditador Alfredo Stroessner se empenhou em "repatriar" os seus restos mortais em 1961, apoiou a publicação de uma biografia enaltecendo-a (PITAUD, 1958) e incentivou a heroicização da irlandesa. ${ }^{6}$

\footnotetext{
4 As residentas foram mulheres, geralmente de camadas sociais mais baixas, que se envolveram ativamente na Guerra da Tríplice Aliança, acompanhando os soldados nos campos de batalha e desenvolvendo tarefas diversas nos acampamentos militares (RODRIGUEZ ALCALÁ, 2011, p. 19-39).

${ }^{5}$ Como nos mostra o historiador Peter Lambert (2013, p. 335-358), a narrativa nacionalista paraguaia surgiu no início do século XX a partir de grupos intelectuais minoritários que passaram a recontar a história do Paraguai de forma mais positiva e heroica, mostrando orgulho em relação ao passado nacional. Dentre os principais nomes vinculados a essa nova tendência, é possível citar Juan O'Leary e Juan Natalicio González. Obviamente, o processo de propagação da narrativa nacionalista não foi linear e sofreu uma série de resistências antes de alcançar hegemonia durante a ditadura militar. Alguns intelectuais críticos à narrativa nacionalista foram Cecilio Báez e Héctor Francisco Decoud.

${ }^{6}$ Além de apoiar livros que exaltavam a "epopeia nacional”, como Rugidos de Leones (MEZA, 1968), que também traz uma imagem nacionalista de Madame Lynch, o ditador financiou o primeiro longametragem paraguaio, lançado em 1978. Cerro Corá trata da última batalha da Guerra da Tríplice Aliança,
}

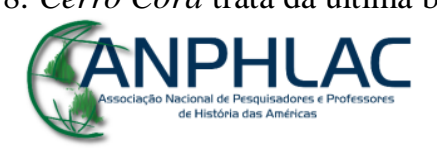

Revista Eletrônica da ANPHLAC, ISSN 1679-1061, №. 24, p. 44-71, Jan./Jun., 2018.

http://revista.anphlac.org.br 
Antes mesmo de Elisa Lynch ser elevada ao posto de heroína nacional, a curiosa personagem já havia atraído a atenção de romancistas e biógrafos, e foi difamada em diversos textos biográficos e jornalísticos durante e após a Guerra da Tríplice Aliança. A partir de fins dos anos 1980, especialmente após a queda da ditadura militar paraguaia em $1989,^{7}$ alguns historiadores procuraram fazer contribuições para compreender essa personagem, utilizando, no entanto, o vasto material biográfico já publicado de forma pouco crítica. Segundo Maria Gabriella Dionisi (2011), professora de Literatura Hispano-americana na Universidade de Tuscia, apenas os biógrafos e os romancistas efetivamente se debruçaram no estudo da personagem.

Como argumentou a historiadora Maria Teresa Dourado, Elisa Lynch se tornou "uma mulher de muitas faces", um mito cujas particularidades são reconfiguradas de diferentes maneiras nas biografias (DOURADO, 2002, p. 30-42). Embora os historiadores já tenham se empenhado em analisar as transformações sucessivas nas leituras sobre o marechal López e o crescimento do lopismo ${ }^{8}$, Madame Lynch ainda não foi alvo desse mesmo esforço. ${ }^{9}$ Tendo, então, a irlandesa como personagem principal deste artigo, a minha pretensão é buscar compreender as primeiras imagens veiculadas a respeito de Madame Lynch antes de ela ser alçada ao posto de heroína nacional paraguaia. Para tanto, seria possível utilizar, por exemplo, os periódicos que circularam durante e após a Guerra da Tríplice Aliança, ${ }^{10}$ porém dada a demasiada dispersão desse

mostrando a valentia e bravura dos paraguaios, especialmente o marechal López, destacando ainda a abnegação e devoção de Madame Lynch em relação à sua "pátria adotiva".

${ }^{7}$ A partir do final dos anos 1980, houve uma renovação historiográfica a respeito da Guerra da Tríplice Aliança, que além de manifestar um vigoroso esforço para superar as leituras nacionalistas sobre o confronto, ainda abriu espaço para o estudo de temas considerados controversos e para as pesquisas que procuram identificar interconexões entre a guerra e a cultura. É possível afirmar que a chamada nova historiografia sobre a Guerra da Tríplice Aliança incitou novos métodos de investigação, atribuindo diferentes significados políticos ao confronto sul-americano, e ainda estimulou a pesquisa sobre a presença de certos grupos sociais nos campos de batalha que não haviam sido estudados até então, como escravos, comerciantes e as mulheres (BREZZO, 2003, p. 157-175).

${ }^{8}$ Alguns pesquisadores que já lidaram com essa temática são Luc Capdevila (2010), Francisco Doratioto (2002), Peter Lambert (2013) e Guido Rodríguez Alcalá (1987).

${ }^{9}$ Em minha pesquisa de Mestrado, ainda em andamento, procuro analisar algumas biografias de Madame Lynch, que foram publicadas em diferentes momentos da história do Paraguai. O objetivo da análise é tentar compreender as relações entre estes materiais, a historiografia sobre a Guerra da Tríplice Aliança em curso no período da publicação e os interesses políticos que podem se esconder nas imagens construídas sobre a irlandesa.

${ }^{10}$ Os periódicos que fizeram publicações que criticavam abertamente Elisa Lynch são múltiplos. Então, sem pretensão de fazer uma listagem exaustiva, é possível citar os jornais cariocas A vida Fluminense e Semana Illustrada e os periódicos argentinos El Mosquito e La Tribuna. Quando a guerra terminou, também surgiu uma imprensa "independente" no Paraguai e absolutamente crítica ao "despotismo" do marechal López e de Elisa Lynch; dentre esses jornais, pode-se citar La Reforma e La Regeneración.

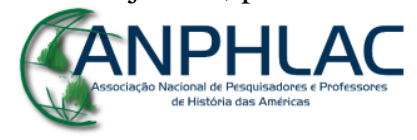

Revista Eletrônica da ANPHLAC, ISSN 1679-1061, №. 24, p. 44-71, Jan./Jun., 2018.

http://revista.anphlac.org.br 
material, optei por analisar a primeira biografia da personagem, publicada ainda em 1870, denominada Elisa Lynch por Orion, escrita pelo famoso jornalista portenho Héctor Florencio Varela. A biografia teve grande importância, ajudando a consolidar e difundir uma determinada interpretação a respeito de Madame Lynch e do Paraguai no pós-guerra, servindo de base fundamental para biografias posteriores.

\section{Reflexões teóricas}

As relações entre a História e os estudos biográficos foram conturbadas durante um longo período de tempo em razão do caráter híbrido das biografias e de sua vocação supostamente pouco científica, muitas vezes aberta excessivamente à subjetividade (DOSSE, 2009). Os esforços para a renovação da historiografia francesa da década de 1970, resultantes da crise dos grandes modelos explicativos e da necessidade de superar a história quantitativa, e que deram origem à Nova História, ainda não contemplavam as biografias (BORGES, 2010). Somente na década seguinte, em 1980, com o desenvolvimento da Nova História Política, ocorreu o chamado retorno da biografia; isto é, a inserção tardia desse gênero na academia (LEVILLAIN, 2003). A abertura das universidades às biografias implicou que os intelectuais reconhecessem os limites e possibilidades desse gênero para que pudessem escrevê-las ou analisá-las como fontes primárias.

Um dos pressupostos do trabalho com esse tipo de documentação é compreender que as biografias não atingem a totalidade da vida do biografado, por mais que a pesquisa seja muito bem documentada. Nesse sentido, o sociólogo francês Pierre Bourdieu (2000) mostrou que as biografias tradicionais são concebidas a partir da preocupação em dar um sentido retrospectivo e esgotar incoerências entre diversos acontecimentos considerados importantes na vida de um indivíduo, de forma a costurálos, dando-lhes uma determinada harmonia. Por isso, não é possível escrever a vida de uma pessoa, mas criar, artificialmente, uma determinada personalidade, que se mostra através de manifestações sucessivas que possuem uma relação inteligível entre si.

Outra importante referência na temática das biografias é o historiador francês François Dosse. Segundo seu importante estudo, denominado O Desafio Biográfico: Escrever uma Vida, os biógrafos se deparam com uma grande pluralidade de reconstruções possíveis sobre um determinado indivíduo; por isso, precisam "preencher

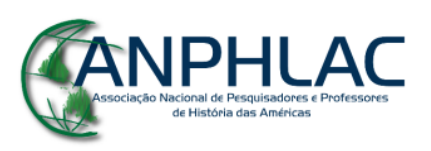

Revista Eletrônica da ANPHLAC, ISSN 1679-1061, №. 24, p. 44-71, Jan./Jun., 2018.

http://revista.anphlac.org.br 
as lacunas documentais e valer-se da intuição para ligar traços descontínuos" (DOSSE, 2009, p. 67) para não recair em uma pulverização infinita de seu biografado. Assim, François Dosse argumentou que todas as biografias são romanceadas em alguma medida, já que não é possível atingir uma verdade sobre a vida ou trajetória de um personagem. Desse modo, as biografias têm o potencial de revelar questões mais importantes a respeito do biógrafo e do contexto no qual ele produz, do que a respeito do biografado em si (DOSSE, 2009, p. 55-80).

Sem perder de vista esses referenciais teóricos, defendo que as biografias - de Madame Lynch ou outras - não possuem a prerrogativa de relevar detalhes verdadeiros a respeito do personagem biografado. Tratando-se de uma construção que geralmente provém de concepções prévias a respeito dos biografados, as biografias permitem que possamos entender os sentidos atribuídos à vida de uma pessoa, a imagem que o biógrafo, sem querer, constrói de si mesmo, e possíveis relações que esses escritos possuem com seu contexto de produção. No caso de Elisa Lynch por Orion, veremos que a obra foi escrita e publicada pouquíssimo tempo após o marechal López ser morto, o Paraguai ser derrotado e Elisa Lynch ser responsabilizada pela tragédia e expulsa do país; em outras palavras, a irlandesa era um alvo fácil e pertinente de seus inimigos políticos.

\section{Elisa Lynch e Héctor Varela: as relações entre a biografada e o biógrafo}

Elisa Alicia Lynch nasceu em 1834 na cidade irlandesa de Cork. ${ }^{11}$ Provavelmente por causa da Grande Fome Irlandesa (1845-1849), ${ }^{12}$ a personagem dirigiu-se para Londres com a sua família ainda na infância e, quando completou dezesseis anos, casou-se com o militar do exército francês, Xavier Quatrefages

\footnotetext{
11 A idade e a nacionalidade de Elisa Lynch são um dos aspectos que mais geraram curiosidade e discordância entre os biógrafos. Héctor Florencio Varela (1870), por exemplo, afirmou que Elisa Lynch provavelmente havia nascido entre 1829 e 1830 na Inglaterra. Jacinto Villa Vicencio (1874), embora não seja um biógrafo de Lynch, afirmou que ela nasceu na Escócia em 1822. Héctor Francisco Decoud (1939), por outro lado, afirmou que ela nasceu na Irlanda em 1831. Na realidade, Madame Lynch nasceu na Irlanda, provavelmente entre 1833 e 1834, e há uma série de documentos que ajudam a comprovar essa alegação, como a certidão de casamento dos seus pais em 1833 e o seu registro de batismo em 1834 , ambos em Charleville, na Irlanda.

${ }^{12}$ A Grande Fome irlandesa foi um desastroso episódio desencadeado por uma infestação agrícola conhecida como "praga da batata" - que se espalhou por plantações de batata de várias regiões da Europa. No caso da Irlanda, a infestação trouxe consequências mais graves, como a emigração em massa e doenças, além da fome propriamente dita. Isso ocorreu devido à forte dependência da batata entre as populações mais pobres da ilha. A Grande Fome é um dos episódios mais presentes na memória coletiva irlandesa e seu legado foi amplamente mobilizado pelo nacionalismo irlandês (KINEALY, 2002).
}

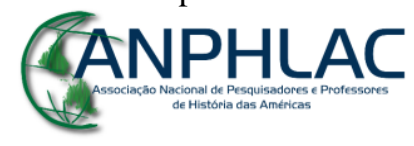

Revista Eletrônica da ANPHLAC, ISSN 1679-1061, №. 24, p. 44-71, Jan./Jun., 2018.

http://revista.anphlac.org.br 
(FANNING; LILLIS, 2009). Por razões especuladas, mas nunca efetivamente explicadas, o casal se separou em $1853 .{ }^{13}$

Pouco após a separação, em 1855, Madame Lynch estava grávida do seu primeiro filho e dirigia-se ao Paraguai, tornando-se companheira do então ministro e general Francisco Solano López, futuro presidente do Paraguai. A forma como ela conheceu o paraguaio também foi alvo de várias especulações. ${ }^{14}$ Quando a irlandesa chegou à América do Sul, sua relação de concubinato com Solano López não era vista positivamente, especialmente pela elite assuncenha. A própria família do presidente Carlos Antonio López, pai de Solano López, recusava-se a manter relações de convivência com Elisa porque ela já havia sido casada anteriormente e tinha um passado que esses segmentos consideravam "nebuloso" (POTTHAST, 2011, p. 220-255).

No ano seguinte à chegada de Lynch ao Paraguai, em 1856, o casal recebeu a visita do jovem portenho Héctor Florencio Varela (1832-1891) que, apesar de se incomodar profundamente com o "despotismo" paraguaio, decidiu viajar a Assunção por estar "gravemente enfermo por conta de uma doença pulmonar" (VARELA, 1870, p. 3). Quatorze anos após essa viagem, em 1870, o jornalista, conhecido pelo pseudônimo Orion, escreveu e publicou uma biografia sobre Madame Lynch. O momento era bastante oportuno para a publicação de um livro sobre ela, uma vez que todo o rio da Prata voltava seus olhos para o Paraguai após o encerramento da Guerra da Tríplice Aliança.

Héctor Varela nasceu em Montevidéu em 1832. Era filho do importante intelectual argentino Florencio Varela, que se encontrava exilado na região do Uruguai desde o começo dos anos 1830, quando o federalista Juan Manuel de Rosas tornou-se governante da Província de Buenos Aires. ${ }^{15}$ De tendência unitária, Florencio Varela

13 Os críticos de Elisa Lynch afirmam que a separação ocorreu devido às suas constantes traições conjugais (VARELA, 1870; DECOUD, 1939). Já seus apologistas alegam que a relação não seguiu adiante porque Lynch não amava seu esposo, e somente encontrou o verdadeiro amor em Francisco Solano López (PITAUD, 1958; LEYES DE CHAVES, 1957).

${ }^{14}$ Assim como a separação de Elisa Lynch e Xavier Quatrefages, também existem diferentes versões a esse respeito. Héctor Decoud (1939) e Héctor Varela (1870) defenderam que ela abandonou o esposo para se tornar cortesã. Henri Pitaud (1958) e Concepción Leyes de Chaves (1957) alegaram que ela não amava Quatrefages e que decidiu abandoná-lo em busca de um verdadeiro amor, que acabou encontrando no paraguaio Francisco Solano López.

${ }^{15}$ Após a independência argentina, as décadas seguintes foram marcadas por uma intensa disputa política entre unitários e federalistas. Em linhas gerais, os unitários defendiam um projeto liberal no qual Buenos Aires, por ser a província economicamente mais importante, teria amplas prerrogativas na gestão do Estado Nacional, como, por exemplo, na formulação de políticas alfandegárias. Os federalistas, por outro lado, defendiam a descentralização radical do Estado Nacional argentino e o protecionismo econômico.

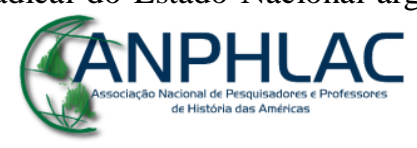

Revista Eletrônica da ANPHLAC, ISSN 1679-1061, №. 24, p. 44-71, Jan./Jun., 2018.

http://revista.anphlac.org.br 
estabeleceu contatos com vários outros intelectuais e políticos argentinos exilados, como Juan Bautista Alberdi, Esteban Echeverría e o ex-governante de Buenos Aires, Bernardino Rivadavia, e fez oposição ao governo Rosas. Em 1848, foi assassinado em Montevidéu, provavelmente por ordens de Juan Manuel de Rosas e Manuel Oribe, em razão de sua notória militância política. O assassinato de Florencio Varela gerou certa comoção no Prata e sua família sofreu sérias dificuldades econômicas nos anos seguintes; seus filhos, no entanto, foram posteriormente reconhecidos como "órfãos da pátria" e, graças a isso, alguns deles conseguiram posições destacadas no espaço público portenho após a queda de Rosas (AMANTE, 2010). Em 1853, os irmãos Héctor e Mariano Varela, filhos do "mártir da liberdade", receberam a imprensa oficial do governo de Buenos Aires e fundaram La Tribuna (1853-1884) (AMANTE, 2010, p. 308), que se tornou um dos periódicos mais influentes e de maior continuidade e circulação em Buenos Aires nos anos 1860 e 1870 (SÁBATO, 1998, p. 49-74).

Ao longo dos quatorze anos que separaram a visita de Orion ao Paraguai e a publicação de Elisa Lynch por Orion, muitas coisas haviam mudado. Héctor Varela havia se tornado uma figura mais conhecida pelo público portenho, por ser editor e proprietário de um dos jornais mais influentes de Buenos Aires, e passou a se envolver em iniciativas públicas que tinham o Estado e o poder público como interlocutores. Seja para organizar manifestações favoráveis à adesão da Argentina à guerra contra o Paraguai em 1865, seja para impulsionar a criação de uma Comissão Popular contra a febre amarela em 1871, ou mesmo para rechaçar a criação de impostos sobre bebidas alcóolicas e o tabaco em 1878, Héctor se preocupava em liderar atos públicos, proferir discursos e organizar celebrações diversas (SÁBATO, 1998, p. 179-211), e, em fins da década de 1860, alcançou uma projeção internacional graças ao seu envolvimento com as ideias americanistas que começaram a crescer na segunda metade do século XIX (BEIRED, 2014). ${ }^{16}$ Do mesmo modo, Elisa Lynch se tornou primeira-dama do

Era um projeto encabeçado pelas elites das províncias do litoral (dos grandes rios) e do interior da Argentina, ainda que alguns membros da elite de Buenos Aires, como Juan Manuel de Rosas, fossem federalistas (PELLEGRINO; PRADO, 2014).

${ }^{16} \mathrm{O}$ envolvimento de Orion na temática remonta, ao menos, ao ano de 1867, quando ele participou do Congreso de la Paz y de la Libertad em Genebra, representando a América Hispânica. Nessa ocasião, diante de uma fala polêmica sobre "os selvagens americanos", Héctor proferiu um discurso em defesa da democracia americana. Esse episódio parece ter sido essencial para divulgar o nome de Varela pela Europa, mas também pela América Hispânica. Alguns anos mais tarde, em 1872, Orion fundou o jornal El Americano que, apesar de contar com a participação de inúmeros intelectuais do período, como Victor

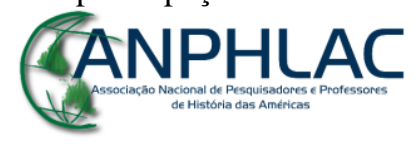

Revista Eletrônica da ANPHLAC, ISSN 1679-1061, №. 24, p. 44-71, Jan./Jun., 2018.

http://revista.anphlac.org.br 
Paraguai, ${ }^{17}$ teve sete filhos com Solano López, viu-se diretamente envolvida na maior guerra sul-americana e se tornou uma personagem bastante conhecida entre os países platinos e o Brasil.

Ao término da Guerra da Tríplice Aliança, com a morte de Solano López, Elisa Lynch foi presa pelo exército brasileiro, teve a grande maioria das suas posses confiscada e foi obrigada a deixar o Paraguai. Símbolo de um poder vencido, Madame Lynch logo foi vilipendiada no imaginário platino e acusada de incitar a Guerra da Tríplice Aliança (DINIZ, 1996, p. 39). Nesse contexto de forte influência política dos aliados, do retorno de exilados políticos (LEWIS, 2016, p. 19-38) e da formação de um novo Estado que congregava agentes de origens diferentes - desde paraguaios que combateram López no exílio, até membros do antigo governo -, a conciliação desses atores políticos se deu através da culpabilização consensual de Francisco Solano López por "seus crimes" e da "influência nociva" de sua amante estrangeira, Elisa Lynch (CAPDEVILA, 2010, p. 173).

No entender de Mauro César Silveira, Madame Lynch foi um dos alvos preferidos da imprensa brasileira, ainda que o espaço concedido a ela fosse, obviamente, muito menor do que as referências ao chefe de governo paraguaio. As leituras sobre ela denunciavam a manipulação da irlandesa sobre o marechal López, a quem ela supostamente influenciava na perpetuação da guerra (SILVEIRA, 2003, p. 37-44). No contexto do pós-guerra, foram produzidos alguns livros de memórias e escritos testemunhais ${ }^{18}$ que trataram de aspectos diversos sobre o confronto armado e ajudaram a compor e difundir uma imagem predominantemente crítica sobre Elisa Lynch.

\section{As imagens de Héctor Florencio Varela sobre a Madame Lynch e o governo paraguaio}

Em relação a Elisa Lynch por Orion, primeira biografia publicada sobre a personagem, Héctor Varela tinha a intenção de escrever três volumes a respeito de

Hugo, Bartolomé Mitre, Carlos Guino Spano, Ricardo Palma e Emilio Castelar, acabou indo à falência em 1874 (MARTINEZ, 2001).

${ }^{17}$ Como já foi mencionado anteriormente, Elisa Lynch foi companheira de Francisco Solano López, que se tornou presidente do Paraguai em 1862; eles nunca puderam se casar, uma vez que a irlandesa já havia sido casada com o oficial francês Xavier Quatrefages. No entanto, o casal Lynch-López teve uma relação pública, teve sete filhos e permaneceu unido até a morte do marechal em 1870. Sendo assim, parece razoável nomeá-la como primeira-dama do Paraguai.

${ }^{18}$ Há uma quantidade considerável de materiais que poderiam ser citados, como por exemplo: Charles A. Washburn (1871), George Frederick Masterman (1870) e Dorotea Duprat de Lassare (1871).

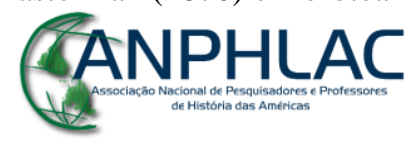

Revista Eletrônica da ANPHLAC, ISSN 1679-1061, №. 24, p. 44-71, Jan./Jun., 2018.

http://revista.anphlac.org.br 
Madame Lynch: o primeiro, sobre uma viagem que ele fez a Assunção em fins de 1855, quando teve a oportunidade de conhecer a personagem e o, então, general Francisco Solano López; o segundo, sobre as aventuras de Lynch na Europa e os lugares que ela costumava frequentar; e o último, sobre a participação dela na Guerra da Tríplice Aliança (VARELA, 1870, p. XV). Por motivos desconhecidos, mas provavelmente ligados ao crescente envolvimento de Orion com o americanismo, ele publicou somente o primeiro tomo de sua obra, denominando-o Elisa Lynch por Orion. Apesar do livro ter sido editado e impresso somente uma vez no século XIX, ${ }^{19}$ o número de vendas foi bastante expressivo na época do lançamento. ${ }^{20}$

Como a obra de Héctor Varela sobre Elisa Lynch não chegou a ser concluída, o único tomo publicado trata da trajetória dela de forma incompleta, considerando os objetivos totais elencados pelo autor. É necessário considerar ainda que, embora o livro não trate exclusivamente e nem exaustivamente da trajetória de Madame Lynch, como uma biografia tradicional geralmente pretende fazer, esse material é central para discutir as imagens que mais circularam a respeito da personagem no pós-guerra. A obra é importante também por ter sido escrita e publicada pelo dono e editor do principal jornal de Buenos Aires, La Tribuna. ${ }^{21}$ Por último, uma questão que precisa ser destacada é que Elisa Lynch por Orion influenciou consideravelmente as leituras posteriores a respeito da personagem; quase todas as biografias subsequentes fazem ao menos uma pequena menção, em geral crítica, ao trabalho de Héctor Varela.

Nas primeiras páginas do livro, Héctor Florencio Varela já deixou manifesta a sua tentativa de conferir maior credibilidade à sua obra. De forma explícita, o escritor reivindicou um estatuto de verdade para a sua narrativa, coroado por uma suposta neutralidade, por sua visita ao Paraguai alguns anos antes da publicação, mas também

\footnotetext{
${ }^{19}$ Posteriormente, o livro foi reeditado novamente em Buenos Aires em duas outras ocasiões, em 1934 e 1997.

${ }^{20}$ Ao iniciar uma série de sete artigos profundamente críticos a respeito de Elisa Lynch por Orion no periódico La República, o escritor Manuel Bilbao fez uma digressão sobre a necessidade de se criticar as obras de forma justa, tanto para elogiá-las, como para depreciá-las, sem que a crítica seja tida como uma ofensa pessoal ao autor. Sugerindo que a obra de Orion foi elogiada cegamente por seus admiradores, Bilbao afirmou que essa reflexão era necessária "porque sendo essa obra aquela que mais tem circulado, que mais tem causado entusiasmo em nossa sociedade, merece, portanto, receber um parecer justo" (BILBAO, 1870, p. 9).

${ }^{21}$ Apesar do surgimento de novos periódicos portenhos em fins de 1860, como La República (1867), La Prensa (1869) e La Nación (1870), La Tribuna (1853) ainda era o principal diário de Buenos Aires em 1870, tanto por seu número de vendas, como por sua influência e por seu prolongado período de atividade (PASTORMELO, 2016).
}

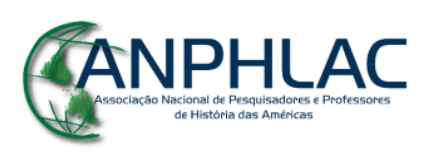

Revista Eletrônica da ANPHLAC, ISSN 1679-1061, №. 24, p. 44-71, Jan./Jun., 2018.

http://revista.anphlac.org.br 
pelo prestígio que seu sobrenome e sua profissão lhe conferiam. A respeito dessa busca pela verdade, Héctor Varela transcreve um trecho de um diálogo que afirma ter tido com Madame Lynch após a guerra, quando ela se encaminhava a Buenos Aires. Nesse momento, a personagem afirma:

\begin{abstract}
- Se o senhor não escrever um livro que me insulte, que me ultraje, em que me mostre como a mais perversa e sanguinárias de todas as mulheres, sua obra não irá encontrar eco.

- Eu não penso em escrever - lhe respondi - um livro destinado a satisfazer aos desejos de ninguém: nem daqueles que acreditam que a senhora é a mais infame de todas as mulheres, nem a ambição daqueles que, pelo contrário, encontram uma desculpa para as suas faltas comedidas ao lado do General [Solano] López. Minha missão se limitará a expor fatos de uma autenticidade que ninguém poderá questionar. Esses fatos são o que julgarão a senhora. ${ }^{22}$ (VARELA, 1870, p. XV) [Grifos originais]
\end{abstract}

Ao tratar das chamadas "escritas de si", a historiadora Angela de Castro Gomes afirmou que "toda essa documentação de 'produção do eu' é entendida como marcada pela busca de um "efeito de verdade"” (GOMES, 2004, p. 15). Sendo assim, esse desejo manifesto de Héctor Varela "expor fatos, cuja autenticidade ninguém poderá questionar" não deve surpreender e nem conferir maior ou menor credibilidade à biografia. As "escritas de si" não podem ser lidas para encontrar verdades ou mentiras, mas para entender o olhar assumido e registrado pelo autor em relação a alguém ou algum acontecimento. Não há neutralidade possível, e sob esse ponto de vista torna-se ainda mais claro que esta biografia é uma construção sobre Elisa Lynch, mesmo que Héctor Varela afirme o contrário.

Apesar do livro ter sido destinado a tratar do momento em que o autor conheceu Madame Lynch, Héctor Varela discorre sobre uma série de outros assuntos que parecem secundários ou até mesmo desnecessários em uma biografia sobre a personagem. Elisa Lynch por Orion possui onze capítulos distribuídos em mais de quatrocentas páginas e teve os argentinos, sobretudo, como público-alvo. Essa afirmação se justifica em razão das longas considerações de Orion a respeito de cidades de diferentes províncias argentinas nas quais o navio a vapor que o transportava precisou aportar e por suas reflexões a respeito da história da Argentina e da "tirania" de Juan Manuel de Rosas. O livro é permeado por referências à Argentina dividida nos anos 1850 e por comparações entre Buenos Aires e o Paraguai. Ao escrever um parecer crítico sobre Elisa Lynch por

\footnotetext{
${ }^{22}$ Esta e todas as traduções subsequentes foram realizadas por mim.

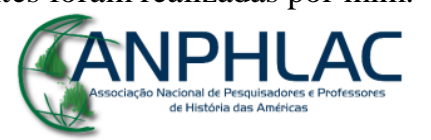

Revista Eletrônica da ANPHLAC, ISSN 1679-1061, №. 24, p. 44-71, Jan./Jun., 2018.

http://revista.anphlac.org.br
} 
Orion no periódico portenho La República, Manuel Bilbao reprovou veementemente as longas divagações de Héctor Varela, que fazem com que Madame Lynch não possua a centralidade que deveria ter em toda a biografia:

Este livro é a história de Elisa Lynch ou a história de uma viagem?

Para nós é a descrição novelesca de um passeio [...]. Não conseguimos entender o que essa viagem tem a ver com uma introdução à vida de Elisa Lynch [...]. Em uma biografia é admitida a reunião de acontecimentos ligados à história do herói. Porém, jamais é permitido fazer da heroína uma personagem secundária, acessória e não dar centralidade a ninguém, deixando que cada cena possua seu herói, sua vida própria, seja um episódio isolado. (BILBAO, 1870, p. 12-14)

De fato, Héctor Varela faz uma série de divagações que não possuem necessariamente relações entre si e que dão, à primeira vista, um caráter caótico ao livro. A obra poderia até mesmo ser enquadrada como um tipo de relato de viagem, o que não a invalidaria necessariamente como uma biografia. ${ }^{23}$

Um dos aspectos que recebe bastante destaque nesse livro é a elegância, sensualidade e a beleza que o escritor atribuía à Madame Lynch. Antes mesmo de conhecê-la pessoalmente, Héctor afirma que tinha alguma consciência dos encantos da misteriosa "dama inglesa" que se tornou "a querida do General López" (VARELA, 1870, p. 233), posto que já havia sido alertado a esse respeito mais de uma vez. Apesar disso, o escritor expressa que ficou bastante surpreso com a aparência física e os trejeitos de Lynch ao conhecê-la pessoalmente:

Se existem mulheres que possuem o privilégio de se impor desde o primeiro instante em que cruzam os olhares de seus semelhantes, digo aqui, com toda sinceridade e independência, que Elisa Lynch me pareceu uma dessas mulheres, ao entrar com desenvoltura e elegância no salão. (VARELA, 1870, p. 260) [Grifo original]

Visivelmente interessado na jovem europeia, o jornalista portenho a descreve com as seguintes palavras:

\footnotetext{
${ }^{23}$ Segundo Jan Borm, o relato de viagem é difícil de ser caracterizado porque é um "gênero composto de outros gêneros", podendo acomodar diários, ensaios, contos, poesias, autobiografias, etc. (BORM, 2004, p. 13-26). Em quase todas as referências localizadas a respeito de Elisa Lynch por Orion - exceto no artigo de Manuel Bilbao -, a obra é definida como uma biografia, assim como neste artigo; apesar disso, é necessário destacar que esse material possui características que vão além de uma biografia tradicional e que enfatiza diversos aspectos relativos à viagem de Héctor ao Paraguai.
}

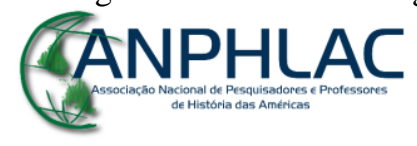

Revista Eletrônica da ANPHLAC, ISSN 1679-1061, №. 24, p. 44-71, Jan./Jun., 2018.

http://revista.anphlac.org.br 
Sua estatura era alta; sua cintura era flexível e delicada, seus contornos eram belos e voluptuosamente desenhados, e apenas eram encobertos por um delicado tule branco que contrastava com a alvura de sua cútis [...]; seus olhos eram de um azul que parecia roubado das tonalidades do céu, e tinham essa expressão inefável de doçura [...]; sua boca não era de todo pequena, mas em seus lábios, muito finos, havia essa expressão indescritível de volúpia que o observador adivinha ou sente ao vê-los úmidos, como se com esse orvalho sublime Deus quisesse apagar o fogo de certas bocas, que se transformariam em cálices de deleite, nos festejos da paixão ardente.

Sua mão era pequena: seus dedos eram largos, suas unhas perfeitamente contorneadas e cuidadas com delicado esmero que, para algumas mulheres, é o culto de seu toilette [enfeitar-se], e uma religião da sua vida. (VARELA, 1870, p. 260)

Embora a personagem seja costumeiramente descrita como uma mulher bela, sedutora e luxuosa, mesmo por seus inimigos políticos, nem todos os autores fazem isso de forma tão direta e acentuada como Héctor Varela o fez nos trechos acima. A adjetivação exagerada e o uso excessivo de metáforas sugerem uma atração física do portenho pela irlandesa. Isso não significa, no entanto, que ele tivesse uma leitura positiva sobre ela, muito pelo contrário. Para o jornalista, Madame Lynch era uma mulher sedutora e inteligente, porém com um caráter absolutamente questionável.

Para podermos compreender melhor o "maravilhamento" de Varela em relação a Elisa Lynch e as imagens que ele constrói a respeito dela, é necessário, primeiro, discutir as leituras elaboradas por Orion a respeito do Paraguai em suas comparações com Buenos Aires. Diferentemente do que afirmou Manuel Bilbao, acredito que essas informações são fundamentais para ajudar Héctor Varela a conceber uma determinada interpretação a respeito do governo paraguaio e dos motivos que levaram Elisa Lynch "a deixar a vida na Europa, para compartilhar uma existência quase primitiva" (VARELA, 1870, p. 270) em Assunção.

Segundo o jornalista, o Paraguai era monitorado por um sistema intenso e coercitivo de espionagem graças ao qual "uma mosca não entraria [em território nacional] sem aviso prévio", e ninguém podia se manifestar publicamente de forma contrária ao presidente e seus familiares. Havia um rechaço profundo aos estrangeiros, especialmente àqueles das províncias de baixo (Argentina), mas também aos brasileiros, aqueles a quem o presidente supostamente designava de cambás. ${ }^{24} \mathrm{O}$ regulamento policial que os estrangeiros deviam obedecer tinha determinações absurdas no entender

\footnotetext{
24 Segundo Héctor Florencio Varela, Carlos Antonio López se referia aos brasileiros como negros, cambás (palavra em guarani que tem o mesmo significado) ou macacos.
} 
de Orion, como a necessidade de se requerer uma autorização policial para comparecer a bailes ou eventos públicos e a imposição dos transeuntes saudarem respeitosamente Carlos López sempre que a carruagem presidencial passasse. Tudo isso era absolutamente inadmissível para Héctor Varela, que se via como

\begin{abstract}
Homem jovem, educado em meio à completa liberdade que sorria à minha Pátria; filho de um povo, que, sejam quais forem seus defeitos [...], possuía, contudo, absoluta consciência de seus direitos e liberdade; alimentado em uma sociedade culta e ilustrada; acostumado ao movimento e agitação que nos são comuns, a fisionomia geral do Paraguai, sua moralidade, sua opressão, seus costumes, os caprichos e excentricidades dos governantes; todo esse conjunto singular e bizarro, no qual a farsa e a barbárie se misturavam, produzia uma impressão de tristeza e dor em meu espírito, dos quais eu não podia me libertar... (VARELA, 1870, p. 279) [Grifo meu]
\end{abstract}

Ao mesmo tempo em que ajuíza negativamente o despotismo paraguaio, Héctor Varela ressalta as qualidades de sua "Pátria". O escritor emprega aqui uma retórica de alteridade, na qual Paraguai e Buenos Aires são retratados em oposição. ${ }^{25}$

Evidentemente, Orion se identificava muito mais como portenho do que como argentino, ainda mais considerando o período de divisão política pelo qual o país atravessava no momento em que ele foi ao Paraguai. E embora ele afirme que foi "educado em meio à completa liberdade" de sua Pátria, em realidade, Héctor nasceu e cresceu no exílio, em Montevidéu. Após a morte de Florencio Varela, seu pai, em 1848, sua família se instalou no Rio de Janeiro (HERNÁNDEZ-PRIETO, 1981). O retorno dos Varela a Buenos Aires ocorreu somente após a derrota de Rosas em $1852^{26}$ e a sua viagem ao Paraguai teve início em setembro de 1855. A biografia Elisa Lynch por Orion foi publicada cerca de quatorze anos depois da viagem, quando a Argentina já estava novamente unida e, então, sob a presidência de Domingo Faustino Sarmiento.

\footnotetext{
${ }^{25}$ Como afirma o historiador francês François Hartog (1999, p. 38) em sua análise sobre a obra de Heródoto, os escritos que têm a preocupação de traduzir o outro, como os relatos de viagem, geralmente fazem uso de retóricas de alteridade. A retórica da alteridade funcionaria como um "espelho em negativo": procurando entender o outro, acabamos levantando um espelho para nós mesmos e enxergamos aquilo que é dissonante com o que somos/acreditamos. Em outras palavras, frequentemente o viajante fala mais sobre si próprio do que sobre o outro. Como exemplo, Hartog menciona que os povos citas surpreenderam Heródoto por não possuírem cidades, casas ou campo lavrado, ou seja, justamente aquilo que os gregos possuíam.

${ }^{26}$ Alguns autores, como Maria Isabel Hernández Prieto (1981) e o próprio Emilio Castelar (VARELA, 1870, p. III-X), afirmam que Orion contribuiu e participou do levante militar liderado por Justo José de Urquiza, que tirou Juan Manuel de Rosas do poder. No entanto, seja por não ter efetivamente tido nenhuma participação, seja por não querer ligar seu nome ao do general Urquiza - que presidia a Confederação Argentina na época da viagem do jornalista -, Héctor Varela negou qualquer envolvimento no levante que derrotou Rosas.
}

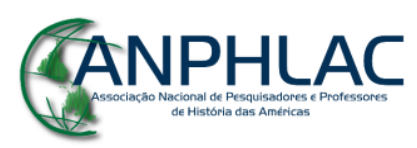

Revista Eletrônica da ANPHLAC, ISSN 1679-1061, №. 24, p. 44-71, Jan./Jun., 2018.

http://revista.anphlac.org.br 
Tendo como referencial a história de seu país, a solução encontrada por Héctor Varela para demonstrar que o Paraguai era primitivo e dominado pelo despotismo foi afirmar que o governo do país era ainda pior do que a tirania de Juan Manuel de Rosas:

\begin{abstract}
O próprio Rosas, por mais bárbaro e sanguinário que fosse, tentava ocultar a ferocidade de suas inspirações, cometendo atos de uma tirania sem precedentes, mas sempre tentando revesti-los e ainda legitimá-los com toda a legalidade formal.

No Paraguai ocorria o contrário.

Longe de tentar esconder, seu Governo aparentemente sentia prazer e satisfação infinita em fazer com que todos compreendessem que a Nação era patrimônio de seu Presidente; que ali não imperava uma vontade maior do que a sua; que somente ele era livre; que a escravidão e submissão deviam ser direitos naturais. (VARELA, 1870, p. 244)
\end{abstract}

Apesar de não ser uma pessoa bem quista no Paraguai, por ser um legítimo representante dos interesses das províncias de baixo, curiosamente, Héctor afirma ter estabelecido boas relações com várias pessoas com atuação pública expressiva em Assunção. Embora o portenho admita que o presidente Carlos López tivesse uma repulsa muito grande em relação a ele, foi convidado mais de uma vez pelo general Solano López para que conversassem e bebessem mate e jerez juntos. Em um desses encontros na casa do paraguaio, Héctor menciona que o general acabou ficando embriagado. Num curioso e inesperado rompante de sinceridade, Solano López disse algo que o jornalista se lembrava perfeitamente e transcreveu quase ao pé da letra:

- [...] minha sorte está completamente ligada ao meu povo. O senhor meu pai
já está velho, sofre de uma enfermidade crônica que, para além de sua idade
avançada, irá precipitar sua morte. Sua vontade e de meus compatriotas é de
que eu o substitua na presidência. Nesse dia eu farei aquilo que ele não quis
fazer, apesar de meus conselhos. Eu sei que o Brasil e vocês, argentinos,
cobiçam o Paraguai. Aqui nós temos elementos suficientes para resistir a
ambos; porém, eu não irei esperar que vocês me ataquem: eu os atacarei.
Diante do primeiro motivo que me derem, declararei guerra ao Império e às
duas Repúblicas do Prata ${ }^{27}$, que apesar de viverem em um clima de
desconfiança mútua, certamente irão se unir para combater-me. (VARELA,
1870, p. 299) [Grifos originais]

\footnotetext{
${ }^{27}$ Neste trecho, Francisco Solano López refere-se a Buenos Aires e à Confederação Argentina. Em 1853, um ano após a queda de Juan Manuel de Rosas, Buenos Aires se separou da Confederação Argentina e permaneceu como Estado Autônomo até 1861. Para Hilda Sábato, a secessão ocorreu porque o projeto de organização nacional de Justo José de Urquiza não reconhecia a hegemonia portenha e determinava que o produto do porto de Buenos Aires deveria ser utilizado em prol do governo nacional (SÁBATO, 2012, p. 17-65).
}

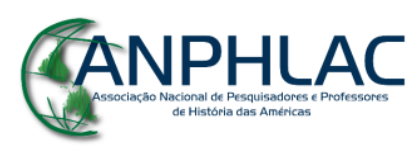

Revista Eletrônica da ANPHLAC, ISSN 1679-1061, №. 24, p. 44-71, Jan./Jun., 2018.

http://revista.anphlac.org.br 
Um dos aspectos que mais chama a atenção em todo o livro é que Héctor Varela sempre pretende se mostrar como alguém importante e tido por confiável pelas pessoas ao seu redor. Isso é um recurso muito utilizado pelo jornalista para mostrar que, sem querer, ele se via constantemente inserido em várias situações que lhe permitem sugerir uma nítida relação entre o que ele via e ouvia no Paraguai e os desdobramentos posteriores da Guerra da Tríplice Aliança. Héctor Varela, como seus contemporâneos, tinha certeza de que a culpa do acontecimento e desenvolvimento do confronto armado era responsabilidade exclusiva do Paraguai. Ele afirma que a guerra era parte do plano de governo do general López, e ele sabia disso porque ouviu o paraguaio proferindo as palavras transcritas acima. Em realidade, se a guerra já estivesse no horizonte político do general López em 1855, é muito pouco provável que ele revelasse seus planos para Héctor Varela, alguém influente em Buenos Aires e que, segundo o próprio autor, manifestava-se publicamente contra o governo paraguaio. De qualquer modo, ainda que não se deva ler esse tipo de fonte em busca de qualquer possibilidade de veracidade histórica, é interessante observar os sentidos retrospectivos que o autor oferece à viagem que fez ao Paraguai, depois que a Guerra da Tríplice Aliança terminou.

Como argumenta Liliana Brezzo (BREZZO, 2005, p. 273-301), no período pósguerra, tanto nos países aliados - Brasil, Argentina e Uruguai -, quanto no país vencido - Paraguai -, a interpretação dominante a respeito das motivações que desencadearam o conflito colocava Francisco Solano López, seu governo "despótico" e "tirânico", como responsável pelo embate armado. Nessa linha argumentativa, as únicas consequências positivas do evento teriam sido a libertação do povo paraguaio de um sistema de "governo tirânico" que o mantinha afastado das "nações civilizadas" e a sedimentação de um ambiente político propício à entrada do liberalismo no Paraguai. Ao se referir à historiografia sobre a Guerra da Tríplice Aliança, o historiador francês Luc Capdevila explica que a interpretação liberal sobre o confronto foi o primeiro modelo explicativo sobre a Guerra da Tríplice Aliança:

Trata-se da versão da história escrita pelos vencedores da guerra. O acontecimento é percebido como o enfrentamento entre a civilização e a barbárie, segundo um prisma de representações anteriormente organizadas por Domingo Faustino Sarmiento para o caso das guerras civis argentinas. [...] A partir dessa perspectiva, todas as responsabilidades se concentraram sobre a loucura mortal do tirano Francisco Solano López, verdugo sanguinário de seu povo e feroz agressor de seus vizinhos. Em fins do século XIX, o autocrata de Assunção foi qualificado como "Nero sul-americano", e

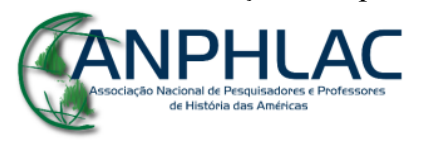

Revista Eletrônica da ANPHLAC, ISSN 1679-1061, №. 24, p. 44-71, Jan./Jun., 2018.

http://revista.anphlac.org.br 
poderia ter sido igualmente estigmatizado como o "Rosas do Paraguai". (CAPDEVILA, 2010, p. 34)

Em relação a essa discussão historiográfica, um aspecto interessante do livro de Héctor Varela é que, embora ele afirme que Francisco Solano López foi o responsável pelo desencadeamento da guerra, ele mostra que Madame Lynch influenciou intensamente a política do então general. Em um determinado momento do livro, logo após fazer uma visita à casa de Madame Lynch, Héctor começa a refletir sobre os motivos que teriam levado uma mulher tão superior "por seu talento e distinta educação" (VARELA, 1870, p. 270) a se dirigir ao Paraguai. O autor parte de duas hipóteses para explicar essa escolha que lhe parecia tão inusitada: em primeiro lugar, Héctor pondera que Elisa realmente podia estar apaixonada pelo general López, opção que ele rejeita imediatamente; a segunda hipótese, que lhe parecia mais plausível, diz respeito às possibilidades de ganhos que a relação com o general poderia oferecer a ela:

\footnotetext{
Elisa Lynch, inteligente e viva, [...] estudou a situação do Paraguai: procurou e encontrou quem a explicasse até os menores detalhes de sua caprichosa e singular existência; soube que a República era patrimônio tradicional daqueles que a governavam [...] despoticamente; soube que Dom Carlos Antonio López já estava velho [...]; calculou que, assim que o velho morresse, a Presidência seria legada ao General (Solano López) como em um testamento; pensou, depois de conhecê-lo intimamente em Paris, que com sua experiência e talento, seria fácil dominar o futuro dono dos destinos da jovem e rica República; e, por meio dessas reflexões sedutoras, percebeu que, enquanto dona absoluta de (Solano) López, por amor e inteligência, poderia chegar a ser mais do que uma Cortesã [...], mas a Presidenta, e talvez a Imperatriz do Paraguai. (VARELA, 1870, p. 272-273)
}

Em seu livro, o jornalista sugere em várias passagens que Elisa foi responsável por influenciar López a declarar guerra no intuito de edificar um império paraguaio para que, finalmente, ela pudesse se tornar imperatriz. Para Héctor Varela, a relação de Solano López e Elisa Lynch foi desequilibrada desde o início. Ainda muito jovem, Elisa Lynch percebeu que o lar modesto de sua família "era pequeno para suas ambições de mulher e suas ilusões de cortesã" (VARELA, 1870, p. XIII). Depois de abandonar a família, a belíssima inglesa recebeu inúmeras promessas de amor, com as quais brincava caprichosamente, abrindo feridas em "corações nobres". Cansada de não possuir um sobrenome que pudesse introduzi-la à alta sociedade, decidiu se casar com um jovem de uma família ilustre. No entanto, a monotonia do casamento a incomodava de sobremaneira que, logo, "teve um amante, teve dois, teve dez, até que as Loretas de

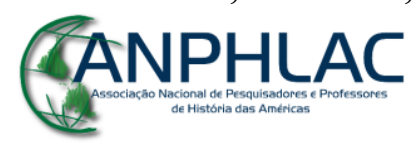

Revista Eletrônica da ANPHLAC, ISSN 1679-1061, №. 24, p. 44-71, Jan./Jun., 2018.

http://revista.anphlac.org.br 
Paris a viram entrar no templo de suas orgias, coroada de beleza e de brilhantes" (VARELA, 1870, p. XIII). Ao conhecer o general López e perceber as vantagens materiais que poderia adquirir se relacionando com ele, Madame Lynch

[...] lhe prometeu a fidelidade de um coração virgem; conseguiu impor sua vontade e o obrigou a viajar com ela para melhor conhecê-lo na intimidade cotidiana, e quando satisfez seu amor próprio, pôde se vangloriar dessa fácil conquista. (VARELA, 1870, p. XIV) [Grifo original]

Encantado com ela, o "general das selvas americanas" decidiu levar Madame Lynch ao Paraguai, onde a impôs a toda sociedade de seu país; todos aqueles que quisessem manter vínculos com o futuro presidente, precisavam ter boas relações com Lynch e tratá-la com toda deferência possível. A esse respeito, Héctor Varela mostra a perseguição sofrida pelo espanhol Ildefonso Bermejo, cuja esposa, Purificación Bermejo, negava-se a ter relações com Madame Lynch. Seduzido por vantagens materiais e pela perspectiva de ligar seu nome aos progressos do Paraguai, Ildefonso decidiu deixar a Europa. Héctor Varela nos explica que, se inicialmente o espanhol era bem tratado pelas pessoas relacionadas ao governo, pouco a pouco foi convertido em uma "máquina de trabalho, apta para tudo", sendo obrigado a realizar todos os caprichos do presidente, sem nunca conseguir agradá-lo e sem ter a possibilidade de abandonar o Paraguai e regressar à Espanha. Toda essa situação foi explicada a Héctor por Purificación Bermejo, que atribuía o sofrimento de seu esposo ao desejo de vingança de Madame Lynch:

- Há aqui uma mulher que, com o sorriso de uma Santa, é um Demônio em corpo e alma: hipócrita, má e perversa. Essa mulher é a concubina do filho mais velho de [Carlos] López. Desde que chegou aqui, procurou-me: visitoume, deu-me presentes; ela tentou, até mesmo com humilhações, estabelecer e intensificar relações comigo. Eu resisti com tenacidade e até mesmo com grosseria. [...] Convencida da debilidade de sua insistência, [...] não pensou em mais nada a não ser em se vingar de mim. [...] Apenas de uma maneira podia me fazer sentir o peso de sua raiva e de seus instintos perversos: vingar-se de mim através de meu pobre marido. (VARELA, 1870, p. 334)

Nesse trecho, Héctor Varela demonstra que Madame Lynch se esforçava ao máximo para conseguir a amizade de Purificación Bermejo. Doña Pura, como ela se tornou conhecida, foi uma senhora espanhola que viajou ao Paraguai para acompanhar seu marido, o publicista e pedagogo Idelfonso Bermejo, que havia sido contratado pelo

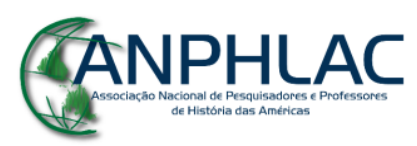

Revista Eletrônica da ANPHLAC, ISSN 1679-1061, №. 24, p. 44-71, Jan./Jun., 2018.

http://revista.anphlac.org.br 
governo. Enquanto Doña Pura se considerava guardiã da moral e da decência, chegando até mesmo a publicar o seu Catecismo de los deberes domésticos de las madres de familia, que era dirigido "às mães de família e às senhoritas que serão", no qual aconselhava fervorosamente a opção pelo casamento formal (POTTHAST, 2011, p. 237), Elisa Lynch era vista como uma figura escandalosa por causa de sua relação de concubinato com o futuro presidente do Paraguai. Por conta disso, a relação entre essas duas mulheres não devia ser de grande proximidade; porém, Orion prefere mostrá-la nos termos de uma tentativa fracassada de amizade que resultou num desejo profundo de vingança.

Para Orion, a influência de Madame Lynch sobre Solano López se estendia desde os aspectos mais insignificantes, como a decoração da casa dele, até elementos fundamentais de sua política, como foi a declaração de guerra. Segundo Varela, já em 1856, as pessoas pareciam ter consciência de que a imposição dos desejos de Lynch podia ser desastrosa. As mulheres da elite paraguaia eram aquelas que mais rejeitavam e odiavam a inglesa, e tinham clareza do papel desempenhado por ela sobre o general López:

- Ela é uma malvada - dizia uma delas, da família de Gill, se a minha memória não me é ingrata - Como nós a depreciamos, ela trata de se vingar, fazendo com que Pancho (o General) nos humilhe em tudo o que pode. Se esta mulher permanecer aqui depois da morte do Presidente, seremos muito desgraçadas. (VARELA, 1870, p. 285)

Toda essa ingerência que Orion alegou que Elisa Lynch possuía sobre o general não implica, por outro lado, que López seria uma pessoa benevolente e simpática ao liberalismo político e econômico se não estivesse sob influência dela. Para o jornalista, foi justamente o conhecido despotismo paraguaio que a atraiu ao país. Portanto, a intervenção de Lynch sobre as ações de Solano López não pretendia modificar o seu caráter, mas levá-lo às últimas consequências. Ainda no entender do escritor, ela podia ter tentado, de outro modo, influenciar o general positivamente, sem encorajá-lo em seus crimes:

Companheira de López nas orgias de Paris, também o foi nas orgias de sangue do Paraguai, em meio das quais essas duas figuras sempre aparecem unidas, em cujas cabeças pairam as almas de milhares de vítimas, muitas das quais ela podia arrancar do martírio, se ao invés de estimular os instintos

\section{CANPHLAC}

Revista Eletrônica da ANPHLAC, ISSN 1679-1061, №. 24, p. 44-71, Jan./Jun., 2018.

http://revista.anphlac.org.br 
ferozes de seu amante, tivesse se inspirado nas recordações da sublime Ester da Bíblia, que se ajoelhava diante de Assuero implorando o perdão dos Hebreus perseguidos por Hamã. (VARELA, 1870, p. XIV)

No trecho acima, Héctor Varela faz referência direta à Ester, personagem que dá nome a um livro do Antigo Testamento da Bíblia. Em linhas gerais, o livro trata dos planos de Hamã, um ministro do rei Assuero, para erradicar os hebreus. De origem judaica, a rainha Ester interveio diante de Assuero, seu esposo, para que ele impedisse a concretização dos planos de Hamã e para salvar os hebreus do extermínio. A evocação dessa narrativa a respeito da ingerência de Ester sobre os atos do rei Assuero serve como contraste em relação à influência de Elisa Lynch sobre o general López; enquanto Ester se esforçou e arriscou a própria vida para salvar os judeus, Lynch estimulava "os instintos ferozes de seu amante".

A evocação de Ester ajuda ainda a sugerir as concepções do jornalista a respeito do papel que as mulheres podiam e deviam assumir na sociedade. Em seu entendimento, a mulher devia estar atrelada à família, uma vez que ela é "uma doce e terna companheira do homem, enviada por Deus em seu caminho, para adoçá-lo e servir-lhe de terna confidente nas horas de atribulação" (VARELA, 1870, p. 254). Para o jornalista, a relação que Lynch estabeleceu com Solano López era absolutamente desequilibrada porque além dela não o amar, ainda o influenciava negativamente para alcançar suas ambições desmedidas. Contudo, apesar de Madame Lynch se mostrar egoísta e imoral com todas as pessoas, admitiu a Héctor, em uma das profundas conversas que teve com ele, que era uma pessoa muito solitária:

Estava visivelmente comovida, e eu ainda mais surpreso.

Tirou de uma pequena bolsa de veludo, que levava sob sua cintura flexível, um lenço de rendas, e o passou leve e graciosamente em seu rosto, dizendome com bondade:

- (...) Eu não tenho uma só pessoa em quem confiar. Entretanto, desejo e necessito dessa fraternidade das almas e dos corações. (VARELA, 1870, p. 396-397)

Dirigindo-se diretamente aos seus leitores, Héctor tenta explicar seu posicionamento a respeito da confissão da inglesa:

Concordo que é difícil, quase impossível, saber quando uma dessas mulheres fala a verdade e quando finge emoções e sentimentos; [...] contudo, naqueles

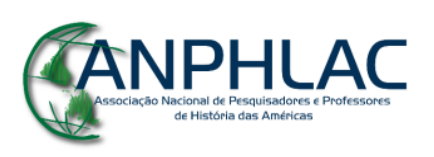

Revista Eletrônica da ANPHLAC, ISSN 1679-1061, №. 24, p. 44-71, Jan./Jun., 2018.

http://revista.anphlac.org.br 
instantes, pareceu-me que havia uma grande sinceridade em todas as palavras de Elisa Lynch. (VARELA, 1870, p. 397) [Grifo original]

As únicas pessoas com quem Madame Lynch conseguia se relacionar minimamente eram homens estrangeiros e agentes diplomáticos de todas as partes do mundo que acreditavam que ela era uma viajante rica que vivia como turista em Assunção. Ciente das visitas que ela recebia, Solano López empregava um espião em sua casa para garantir que ela não o traísse, já que ele sabia que não a havia encontrado em um "lar de virtude e de castidade" (VARELA, 1870, p. 275). Assim, apesar de viver no mais absoluto luxo e se relacionar com um homem poderoso, ela era uma mulher solitária e, no fundo, infeliz. A surpresa e pesar que Héctor parece manifestar por Madame Lynch não podem ser lidos, entretanto, como um ato de generosidade ou de compreensão do portenho em relação aos possíveis dissabores da inglesa. Se, apesar de tudo, ele realmente se importasse com um possível sofrimento dela, provavelmente não teria se empenhado tanto para escrever essa biografia e, muito menos, para publicá-la pouquíssimo tempo depois da guerra.

Como argumenta Leonor Arfuch, a produção de biografias não é um trabalho que pode ser descolado do seu público-alvo, "que busca nelas esse algo a mais que ilumine o contexto vital da figura de algum modo conhecida - dificilmente se lê a biografia de um personagem que se desconhece" (ARFUCH, 2010, p. 140). Embora ele não seja um apologista de Madame Lynch, Héctor Varela se empenha em trazer "algo mais" em relação aos testemunhos e publicações da imprensa platina, que trataram a personagem de forma mais simplista e dicotômica. O que Orion tenta mostrar de forma indireta com os trechos transcritos anteriormente sobre a infelicidade de Madame Lynch, é que ela era uma mulher solitária por causa da vida licenciosa que levava e, em razão disso, nenhuma das mulheres da elite de Assunção queria se relacionar com ela. Igualmente, por isso ela tentava insistentemente estabelecer uma amizade com Purificación Bermejo, por exemplo. Ao perceber que suas investidas não tinham sucesso, Madame Lynch se vingava de suas inimizades através do general López. Para Orion, Elisa Lynch não era simplesmente uma mulher má, mas, primeiramente, uma mulher mundana, infeliz e solitária.

Apesar da obra não estar completa e deste livro ser dedicado a narrar a viagem que Héctor Varela fez ao Paraguai em fins de 1855, é possível afirmar que o autor

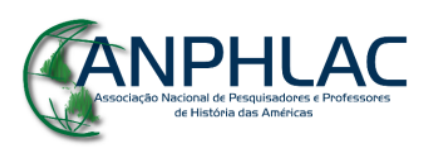

Revista Eletrônica da ANPHLAC, ISSN 1679-1061, №. 24, p. 44-71, Jan./Jun., 2018.

http://revista.anphlac.org.br 
constrói um quadro razoavelmente amplo a respeito de como ele entendia o caráter de Elisa Lynch e de qual teria sido a sua ingerência política no Paraguai. Por mais que Orion não fale como Madame Lynch influenciou Solano López a declarar guerra, por exemplo, ele afirma claramente que ela desejava se tornar imperatriz e que foi justamente o despotismo que reinava no Paraguai que a atraiu ao país; a forma como esse desejo se conectaria à ação de López fica a cargo da imaginação do leitor. Quando a Tríplice Aliança derrotou o Paraguai em 1870, no mesmo ano em que a biografia foi publicada, essas considerações de Héctor Varela a respeito de Madame Lynch podiam soar muito convincentes para aqueles que consideravam o país guarani como causador da maior guerra ocorrida na América do Sul; nesse momento, era bastante conveniente responsabilizar Solano López, um homem morto, e conferir uma série de atributos negativos à Elisa Lynch, uma mulher estrangeira, que se tornou um alvo fácil para seus inimigos políticos.

Como Elisa Lynch por Orion foi escrita e publicada cerca de quatorze anos após a viagem de Héctor Varela ao Paraguai, é muito difícil afirmar se ele realmente se incomodava tanto com o sistema político paraguaio ou se Madame Lynch lhe parecia tão ambiciosa quanto ele afirmou ao longo da biografia. Na realidade, é muito provável que não ${ }^{28}$, mas o que importa perceber é como essa biografia estabelecia um diálogo muito intenso com a leitura liberal sobre a Guerra da Tríplice Aliança, que colocava o Paraguai como um país atrasado e dominado pela tirania de seus governantes. Ao mesmo tempo em que Héctor destaca a ignorância, a opressão e o atraso do outro, enfatiza a liberdade, a modernidade, a moralidade e erudição de Buenos Aires.

Após o livro de Héctor Varela, foram publicadas outras obras que tratam da trajetória da Elisa Lynch e que constroem um retrato semelhante da personagem, no qual ela figura como uma cortesã ambiciosa, manipuladora, que, consequentemente, não possuía qualquer apreço pelo Paraguai, chegando ao ponto de incitar a declaração de guerra; ${ }^{29}$ os inúmeros materiais que discutem a atuação de Elisa na política paraguaia

\footnotetext{
${ }^{28}$ Como afirma Maria Victoria Baratta, o periódico La Tribuna expressava uma postura ocasionalmente favorável ao governo de Carlos Antonio López em suas disputas fronteiriças com o Brasil nos anos 1850. Preocupada, no entanto, em fazer uma discussão mais ampla a respeito do posicionamento dos periódicos argentinos durante a Guerra da Tríplice Aliança, a historiadora não se propõe a discutir qual a postura do La Tribuna em relação ao sistema político paraguaio, fazendo considerações muito breves a esse respeito (BARATTA, 2014).

29 Esse é o caso, por exemplo, do depoimento de William Stewart, do Médico-diretor do exército paraguaio, de Silvestre Aveiro, secretário do marechal López, dos textos de memória de Héctor Decoud,
}

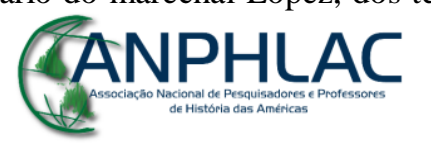

Revista Eletrônica da ANPHLAC, ISSN 1679-1061, №. 24, p. 44-71, Jan./Jun., 2018.

http://revista.anphlac.org.br 
mobilizam representações de gênero que servem para deslegitimar qualquer inserção positiva que a personagem pudesse possuir na esfera pública paraguaia. Assim como em Elisa Lynch por Orion, os escritores não têm nenhuma preocupação em oferecer evidências que possam comprovar as informações apresentadas e, em alguns casos, eles reivindicam que o fato de terem tido a oportunidade de conhecê-la, ainda que apenas por poucos encontros, era suficiente para atestar a veracidade de suas declarações.

Em 1875, cinco anos após o encerramento da Guerra da Tríplice Aliança e a publicação de Elisa Lynch por Orion, Madame Lynch retornou ao Paraguai para reivindicar a devolução de seus supostos bens confiscados pelo Estado paraguaio. Apesar da tentativa, ela foi novamente expulsa do Paraguai poucas horas após chegar ao país, foi ameaçada de morte e, obviamente, não conseguiu recuperar os bens reivindicados. Nessa situação, ela publicou em Buenos Aires um texto autobiográfico chamado Exposición y Protesta (1875), onde tentou se defender das acusações que eram dirigidas contra ela, fazendo referência direta aos livros publicados a seu respeito e exigindo a devolução dos bens baseando-se em uma série de argumentos jurídicos. Nada disso funcionou e Elisa permaneceu como persona non grata no Paraguai mesmo após falecer em 1886. A transformação oficial do status dessa personagem somente aconteceu durante a ditadura militar, quando ela adentrou o cânone nacionalista paraguaio.

\section{Conclusões}

Como procurei argumentar ao longo deste artigo, a biografia Elisa Lynch por Orion foi um dos relatos mais importantes a respeito dessa célebre personagem. Em razão de seu pioneirismo e de sua interlocução com a historiografia liberal sobre a Guerra da Tríplice Aliança, a obra auxiliou na difusão e consolidação de uma determinada leitura a respeito de Madame Lynch. Apesar de ajudar a solidificar uma interpretação crítica sobre essa mulher, seria errôneo afirmar que as informações e opiniões veiculadas por Héctor Varela a respeito da irlandesa constituíram uma unanimidade entre os setores liberais.

Ainda que se discorde de Manuel Bilbao quando ele negou o caráter biográfico do livro, é inegável que Orion tinha uma série de preocupações que iam além das

cuja família foi perseguida pelo governo paraguaio, e do livro Dictadura del Mariscal López de Jacinto Villa Vicencio (1874).

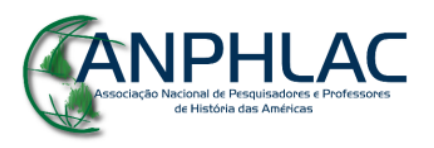

Revista Eletrônica da ANPHLAC, ISSN 1679-1061, №. 24, p. 44-71, Jan./Jun., 2018.

http://revista.anphlac.org.br 
imagens que ele tentava veicular sobre sua protagonista. Elisa Lynch por Orion, na realidade, foi uma obra produzida e publicada às pressas, para que pudesse adentrar o circuito comercial quando a Guerra da Tríplice Aliança e a expulsão de Elisa ainda estavam na ordem do dia; talvez fosse inoportuno escrever um trabalho que se restringisse exclusivamente à trajetória da irlandesa. Sendo assim, ele se preocupou em desenhar sim um quadro de Elisa Lynch, mas inserindo-o dentro do contexto político com o qual ele dialogava, sem perder de vista a vitória da Tríplice Aliança sobre o Paraguai e a hegemonia de Buenos Aires na Argentina.

Além de Varela se preocupar em reforçar a supremacia buenairense, a obra também estabelece uma retórica de alteridade, na qual o Paraguai é retratado em oposição a Buenos Aires. Em meio ao despotismo paraguaio e o incremento dos planos bélicos de Solano López, sobressai-se a sensualidade, o luxo e a amargura de Madame Lynch. As imagens construídas artificialmente sobre a irlandesa estão diretamente relacionadas com a interpretação liberal sobre a Guerra da Tríplice Aliança e mobilizam representações de gênero que dizem respeito ao lugar social que as mulheres deviam ocupar, na opinião do portenho.

Ainda que Varela não tenha se mostrado favorável à Elisa Lynch, o seu olhar curioso e sua atração física pela irlandesa foram elementos suficientes para que outros autores, vinculados ao liberalismo no Paraguai, atribuíssem a Varela a alcunha de "seu destemido defensor", como foi o caso de Héctor Francisco Decoud (1939, p. 13), intelectual paraguaio que escreveu uma biografia marcadamente mais radical e repreensora sobre a mesma personagem quando o nacionalismo lopista crescia no Paraguai. Já durante a ditadura militar paraguaia, quando Elisa Lynch foi elevada à categoria de heroína nacional, Héctor Varela foi denominado como um "panfletista miserável e vil" (O’LEARY, 1971, p. 14) por Juan O’Leary, um dos autores mais reconhecidos do revisionismo paraguaio.

Obviamente, tanto a interpretação liberal quanto o revisionismo historiográfico já podem ser considerados ultrapassados dentro das principais universidades e em grupos de pesquisadores acadêmicos. Contudo, embora a nova historiografia sobre a Guerra da Tríplice Aliança tenha procurado superar o nacionalismo lopista e as leituras antilopistas, no intuito de oferecer uma interpretação crítica sobre a história do Paraguai, a ditadura militar paraguaia conseguiu cristalizar a imagem do marechal

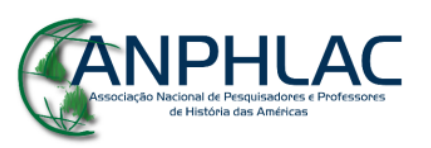

Revista Eletrônica da ANPHLAC, ISSN 1679-1061, №. 24, p. 44-71, Jan./Jun., 2018.

http://revista.anphlac.org.br 
López e de sua companheira Elisa Lynch como heróis nacionais para alguns setores políticos paraguaios, como demonstra a recente tentativa de transladar os restos mortais da irlandesa para o Panteón Nacional de los Heroes. ${ }^{30}$

Apesar de ser intensamente reprovada tanto por críticos como por apologistas da irlandesa, Elisa Lynch por Orion deu início a uma longa série de escritos que pretendem explorar a trajetória de Lynch e é uma das biografias mais citadas nos escritos subsequentes, inclusive em trabalhos mais recentes, como é o caso da biografia escrita pelos irlandeses Michael Lillis e Ronan Fanning (2009). A irlandesa segue intrigando romancistas, biógrafos e, mais recentemente, documentaristas. ${ }^{31}$ Em 1870, ao publicar Elisa Lynch por Orion, Héctor Florencio Varela, sem querer, ajudava a dar início ao processo de mitificação de Madame Lynch, que se arrasta até a atualidade.

\section{Referências Bibliográficas}

AMANTE, Adriana. Poéticas y políticas del destierro. Argentinos en Brasil en la época de Rosas. Buenos Aires: Fondo de cultura económica, 2010.

ARFUCH, Leonor. A vida como narração. In: O espaço biográfico: dilemas da subjetividade contemporânea. Rio de Janeiro: Editora UERJ, 2010, p. 111-150.

BARATTA, Maria Victoria. Representaciones de Paraguay en Argentina durante la Guerra de la Triple Alianza, 1864-1870. Revista SURES, Foz do Iguaçu, n. 4, 2014, p. 41-53.

BEIRED, José Luis Bendicho. Hispanismo e latinismo no debate intelectual iberoamericano. Varia História, Belo Horizonte, v. 30, n. 54, 2014, p. 631-354.

\footnotetext{
${ }^{30}$ No centro de Assunção, há um monumento, denominado Panteón Nacional de los Heroes, que possui funções religiosas, além de abrigar os restos mortais de "heróis" paraguaios, como o marechal Francisco Solano López. Durante a ditadura militar paraguaia, houve a tentativa de transferir a urna funerária de Elisa Lynch para o mesmo local; porém, isso acabou não acontecendo por pressões populares contrárias à medida. Em 1970, foi construído um túmulo para Madame Lynch no cemitério La Recoleta de Assunção, aonde seus restos mortais foram levados definitivamente (CAPDEVILA, 2010, p. 245). Mais recentemente, no ano do bicentenário da independência paraguaia, em 2011, alguns membros da Academia de História Dr. Blas Garay, da Faculdade de direito da UNA (Universidad Nacional de Asunción), solicitaram ao Congresso Paraguaio o traslado dos restos de Lynch ao Panteón. A iniciativa, porém, não obteve o sucesso esperado. Cf. Madame Lynch al Panteón. ABC color, Paraguay, 13 de novembro de 2011. Disponível em: http://www.abc.com.py/edicion-impresa/politica/madame-lynch-alpanteon-332017.html Acesso em: 30 de dezembro de 2017.

${ }^{31}$ Em 2013, Elisa Lynch protagonizou um documentário baseado na biografia escrita por Michael Lillis e Ronan Fanning (2009). O documentário, denominado Eliza Lynch: Queen of Paraguay, foi exibido no Paraguai em um festival de cinema em 2016. O longa-metragem é de difícil acesso no Brasil, uma vez que não adentrou o circuito comercial e não existe a possibilidade de assisti-lo online. Cf. RAMÍREZ, Marisol. La película sobre Elisa Lynch se estrena mañana en festival de cine. Ultima hora, Paraguay, 21 de outubro de 2016. Disponível em: http://www.ultimahora.com/la-pelicula-elisa-lynch-se-estrenamanana-festival-cine-n1033358.html Acesso em: 30 de dezembro de 2017.
}

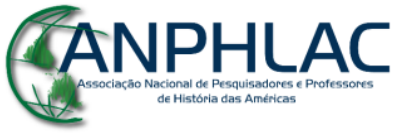

Revista Eletrônica da ANPHLAC, ISSN 1679-1061, №. 24, p. 44-71, Jan./Jun., 2018.

http://revista.anphlac.org.br 
BILBAO, Manuel. Elisa Lynch por Orion. Juicio crítico dado por el diario La República. Buenos Aires: Imprenta, litografía y fundición de tipos, de la sociedad anónima, 1870.

BORGES, Vavy Pacheco. Grandezas e misérias da biografia. In: PINSKY, Carla Bassanezi. Fontes Históricas. São Paulo: Contexto, 2010, p. 203-233.

BORM, Jan. Defining Travel: On Travel Book, Travel Writing and Terminology. In: HOOPER, Glenn; YOUNGS, Tim. Perspectives on Travel Writing. London: Ashgate, 2004, p. 13-26.

BOURDIEU, Pierre. A ilusão biográfica. In: AMADO, Janaína; FERREIRA, Marieta de Moraes (Orgs.). Usos \& abusos da história oral. $3^{\text {a }}$ ed., Rio de Janeiro: Fundação Getúlio Vargas, 2000, p. 183-191.

BREZZO, Liliana. La historiografía paraguaya: del aislamiento a la superación de la mediterraneidad. Diálogos, Maringá, v. 7, 2003, p. 157-175.

BREZZO, Liliana. La guerra de la triple alianza en los límites de la ortodoxia: mitos y tabúes. Revista Universum, Talca, v. 19, n. 1, 2005, p. 10-27.

CAPDEVILA, Luc. Una Guerra total: Paraguay, 1864-1870. Ensayo de historia del tiempo presente. Buenos Aires: Editorial Sb, 2010.

DECOUD, Héctor Francisco. Elisa Lynch de Quatrefages. Buenos Aires: Libreria Cervantes, 1939.

DINIZ, Alai Garcia. O corpo feminino no imaginário da guerra do Paraguai. Travessia Revista de Literatura, Florianópolis, n. 32, 1996, p. 34-44.

DIONISI, Maria Gabriella. Novelando se escribe la historia: De lo dramático a lo espectacular. In: CASAL, Juan Manuel; WHIGAM, Thomas L. (Orgs.). Paraguay en la historia, la literatura y la memoria. II Jornadas Internacionales de Historia del Paraguay en la Universidad de Montevideo. Asunción: Tiempo de Historia/Universidad de Montevideo, 2011, p. 207-227.

DOSSE, François. O Desafio Biográfico: Escrever uma Vida. Tradução de Gilson César Cardoso de Souza. São Paulo: Edusp, 2009.

DOURADO, Maria Teresa Garritano. Mulheres comuns, senhoras respeitáveis. A presença feminina na Guerra do Paraguai. 2002. 131 f. Dissertação (Mestrado em História) - Universidade Federal de Mato Grosso do Sul, Dourados.

FANNING, Ronan; LILLIS, Michael. Calúnia - Elisa Lynch e a Guerra do Paraguai. São Paulo: Terceiro nome, 2009.

GOMES, Angela de Castro (Org.). Escrita de si, escrita da História. Rio de Janeiro: Editora FGV, 2004.

\section{GANPHLAC}


HARTOG, François. Introdução. $O$ espelho de Heródoto. Ensaio sobre a representação do outro. Tradução de Jacyntho Lins Brandão, Belo Horizonte: Editora UFMG, 1999.

HERNÁNDEZ-PRIETO, María Isabel. Héctor Florencio Varela en Madrid (18811885). Aportación a la historia del americanismo en España. Anales de Literatura Hispanoamericana, Madrid, v. 9, n. 10, 1981, p. 127-139.

KINEALY, Christine. The great Irish famine. Impact, ideology and rebellion. Houndmills: Palgrave, 2002.

LAMBERT, Peter. El discurso nacionalista en el Paraguay: Desde lo disidente a lo hegemónico. In: CASAL, Juan Manuel; WHIGAM, Thomas L. (Orgs.). Paraguay: Investigaciones de historia social y politica. III Jornadas Internacionales de Historia del Paraguay en la Universidad de Montevideo. Asunción: Tiempo de Historia/Universidad de Montevideo, 2013, p. 345-358.

LEVILLAIN, Philippe. Os protagonistas: da biografia. In: RÉMOND, René (Org.). Por uma história política. Tradução de Dora Rocha, Rio de Janeiro: FGV, 2003.

LEWIS, Paul. Partidos políticos y generaciones en Paraguay (1869-1940). Asunción: Editorial Tiempo de Historia, 2016.

LEYES DE CHAVES, María Concepción. Madame Lynch - Evocación. Buenos Aires: Peuser, 1957.

Madame Lynch al Panteón. ABC color, Paraguay, 13 de novembro de 2011. Disponível em: http://www.abc.com.py/edicion-impresa/politica/madame-lynch-al-panteon-332017.html Acesso em: 30 de dezembro de 2017.

MARTINEZ, Frédéric. El impacto del viaje. In: El nacionalismo cosmopolita. La referencia europea en la construcción nacional en Colombia, 1845-1900. Bogotá: Banco de la Republica/ Instituto francés de estudios andinos, 2001.

O’LEARY, Juan E. Prólogo. In: PITAUD, Henry. Madama Lynch. Asunción: Editorial France-Paraguay, 1971, p, 11-15.

PASTORMELO, Sergio. Sobre la primera modernización de los diarios en Buenos Aires. Avisos, noticias y literatura durante la Guerra Franco-Prusiana (1870). In: DELGADO, Verónica; ROGERS, Geraldine (Orgs.). Tiempos de papel. Publicaciones periódicas argentinas. (siglos XIX-XX). La Plata: Universidad de Nacional de La Plata, 2016, p. 13-37.

PELLEGRINO, Gabriela; PRADO, Maria Ligia. História da América Latina. São Paulo: Contexto, 2014.

POTTHAST, Barbara. ¿"Paraíso de Mahoma" o "País de las Mujeres"? El rol de la familia en la sociedad paraguaya del siglo XX. Asunción: Fausto Ediciones, 2011.

SÁBATO, Hilda. Historia de la Argentina, 1852-1890. Buenos Aires: Siglo Veintiuno, 2012.

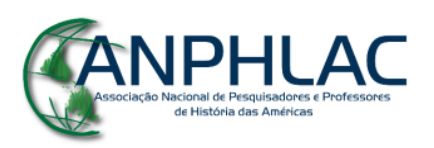

Revista Eletrônica da ANPHLAC, ISSN 1679-1061, №. 24, p. 44-71, Jan./Jun., 2018.

http://revista.anphlac.org.br 
SÁBATO, Hilda. La política en las calles. Entre el voto y la movilización. Buenos Aires, 1862-1880. Buenos Aires: Editorial Sudamericana, 1998.

RAMÍREZ, Marisol. La película sobre Elisa Lynch se estrena mañana en festival de cine. Ultima hora, Paraguay, 21 de outubro de 2016. Disponível em: http://www.ultimahora.com/la-pelicula-elisa-lynch-se-estrena-manana-festival-cine-n1033358.html Acesso em: 30 de dezembro de 2017.

RODRÍGUEZ ALCALÁ, Guido. Introducción. In: (Org.). Residentas, destinadas y traidoras. Testimonio de mujeres de la Triple Alianza. Asunción: Servilibro, 2011, p. 19-39.

SILVEIRA, Mauro César. Madame Lynch e as mulheres nos campos de batalha. In: . Adesão fatal: a participação portuguesa na Guerra do Paraguai. Porto Alegre: EDIPUCRS, 2003, p. 337-344.

VARELA, Héctor Florencio. Elisa Lynch por Orion. Buenos Aires: Imprenta de La Tribuna, 1870. 